\title{
ELABORATION OF AN OPTIMAL MODEL FOR THE DEVELOPMENT OF GASTRONOMIC TOURISM IN THE RIGHT-BANK POLISSIA OF UKRAINE
}

\author{
Inna NESTERCHUK \\ Polissia National University, Faculty of Economics and Management, Department of \\ Tourism, Old Boulevard Street, 7, 10008, Zhytomyr, Ukraine, e-mail: nester_geoek@ukr.net \\ Anna OSIPCHUK* \\ Polissia National University, Faculty of Economics and Management, Department of \\ Tourism, Old Boulevard Street, 7, 10008, Zhytomyr, Ukraine, e-mail: annaosipchuck@ukr.net

\section{Eduard BONDARENKO} \\ Taras Shevchenko National University of Kyiv, Faculty of Geography, Department of \\ Geodesy and Cartography, ave. Academician Glushkov, 2, 03680, Kyiv, Ukraine, e-mail: edbe@ukr.net
}

Svitlana TYSHCHENKO

Polissia National University, Faculty of Economics and Management, Department of Tourism, Zhytomyr, e-mail: kadiss@ukr.net

\section{Oksana TRUSIJ}

Taras Shevchenko National University of Kyiv, Faculty of Geography, Department of Economic and Social Geography, ave. Academician Glushkov, Kyiv, Ukraine, e-mail: oktrusij@ukr.net

\begin{abstract}
Citation: Nesterchuk, I., Osipchuk, A., Bondarenko, E., Tyshchenko, S., \& Trusij, O. (2021). ELABORATION OF AN OPTIMAL MODEL FOR THE DEVELOPMENT OF GASTRONOMIC TOURISM IN THE RIGHT-BANK POLISSIA OF UKRAINE. GeoJournal of Tourism and Geosites, 38(4), 1107-1117. https://doi.org/10.30892/gtg.38416-750
\end{abstract}

\begin{abstract}
Based on the study of spatial forms of tourism organization, their structure and patterns of formation to prove that the most optimal form is a cluster model of organization. Also to describe the features, structure, composition and life cycle of potential tourist clusters of the object of study. In the process of substantiating the development of a cluster model on the Right-Bank Polissia of Ukraine the authors used a combination of general and special methods of scientific research (modeling, information, cluster analysis, geoinformation mapping). It is proved that the creation of regional clusters of gastronomic tourism development of the Right-Bank Polissia of Ukraine will lead to the strengthening of competitive advantages of its participants. The proposed cluster model has been visualized cartographically, also its administrative and functional structure has been developed. Substantiated clusters of gastronomic tourism of the region will become the basis for further scientific research aimed at dividing the territory of the Right-Bank Polissia of Ukraine on the basis of the operational units allocation for gastronomic and tourist zoning.
\end{abstract}

Key words: gastronomic tourism, Right-Bank Polissia of Ukraine, cluster model, potential clusters, life cycle, cartographic visualization, management structure, functional structure

\section{INTRODUCTION}

The global economy has a wealth of experience with different spatial models of development. The greatest successes are those adapted to the practical implementation of projects aimed at enhancing the competitiveness of individual companies and territories. In the course of the market transformation of the Ukrainian economy, processes of expanding the scale and increasing the role of service industries have developed. In this regard, the rapid development of tourism in many regions of Ukraine actualizes the problems of effective use of existing tourism resources and the development of regional centres of economic growth through innovation - tourism and recreation complexes.

Aspects related to spatial organisation, structure and development are important for the regional economy. Forming a regional policy that meets modern requirements for efficiency and sound decision-making is impossible without dealing with the spatial organisation of the region and its characteristics. The current territorial structure of Ukraine's regions is determined by the principles of production location designed in the post-Soviet period. In this context, the issue of spatial imbalances within individual regions of the country is becoming increasingly relevant, and the characterisation of interactions between economic agents in the region is important for addressing these imbalances.

In view of the transformation of Ukraine's socio-economic space over the last two decades, the search for new, more efficient forms of economic organisation has been taking place. Given that the current economic development of the country's regions has a pronounced social orientation, one of the functions of the state is to develop tourism as a means of fully satisfying the recreational needs of its citizens. Tourism industry plays a major role in improving the quality and

\footnotetext{
* Corresponding author
} 
standard of living of the population, as it ensures the recovery of physical and spiritual strength of the population, the maintenance of working capacity, the enhancement of the image of the territory, etc. Sustainable territorial organisation of tourism is an important area of tourism development, and geographical location of tourism enterprises and facilities is a guarantee of efficient use of resources available in the region (recreational, financial, labour, etc.) and satisfaction of tourism and recreational needs of the population of a particular region and the country as a whole. Their effective allocation and management allows solving both economic and social problems of regional and municipal development through: providing recreation, recreation and recovery of regional population; increasing employment; attracting foreign investment to the region, etc. This article is devoted to the above issues, with the specialization of the study area (the Right-Bank Polissia of Ukraine) for the development of gastronomic tourism, the relevance of which is undoubted. The purpose of the work is to substantiate the expediency of the study of spatial forms of tourism organisation, their structure and patterns of formation, and to determine the optimal form of gastronomic tourism development, typical for the Right-Bank Polissia of Ukraine.

The purposes are subordinated to such set for consecutive performance of the task:

- consider and characterise the existing attributes by which spatial forms of tourism are formed;

- identify the best contemporary spatial form of tourism development;

- substantiate the directions of creating tourism clusters for the development of the research area (the Right-Bank Polissia of Ukraine);

- to prove that the creation of regional clusters for the development of gastronomic tourism in the Right-Bank Polissia of Ukraine leads to the strengthening of competitive advantages of its participants;

- describe the characteristics, structure, composition and life cycle of tourism clusters of the object of study as a whole;

- identify the most successful model for the development of gastronomic tourism in the Right-Bank Polissia of Ukraine;

- visualize by cartography the cluster model for the development of gastronomic tourism in the Right-Bank Polissia of Ukraine, determine its managerial and functional structures.

\section{MATERIALS AND METHODS}

In the process of this study the authors applied general scientific and special methods, among which the main are: methods of analysis and synthesis used for the study of experience of regional tourism development; method of scientific classification, comparative, modeling method - for the implementation of certain tasks to study the spatial forms of tourism organization, their structure and regularities of formation, as well as determination of the optimal form of tourism development, typical for the Right-Bank Polissia of Ukraine; informational method - for systematization of primary knowledge about regional tourism development; method of cluster analysis - for distribution of a certain sample of objects into subsets (clusters) for optimization of regional tourism development; method of geoinformation mapping - for direct creation and visualization of cartographic model of gastronomic tourism development of the Right-Bank Polissia of Ukraine on the basis of clusters. Consolidating method of research is a systematic approach, which is used at all the stages and is considered in interconnected aspects through the conceptual framework of creation and application of a single algorithm of the optimal model for the development of gastronomic tourism in the the Right-Bank Polissia of Ukraine.

The informational background of the work served domestic and foreign publications, data from the State Statistics Service of Ukraine in the Kyiv, Zhytomyr, Rivne and Volyn regions. Also authors used personally collected materials in the study area.

\section{RESULTS AND DISCUSSION}

Analysis of scientific sources based on the results of foreign and domestic studies of regional tourism development (Myhaylichenko, 2012; Trusova et al., 2020; Feser et al., 2008) revealed a large number of definitions and concepts characterizing the territorial organization of tourism, such as: "system", "district", "region", "complex", "cluster" and others. Approaches to the study of regional tourism development and spatial forms of tourism organisation are presented in Figure 1. Most of the terms emphasise the complexity and multi-component forms of organising tourism activities. Some researchers pay attention to the geographical location of tourism

Industry enterprises in terms of territorial integrity (Zorin and Kvartalnov, 2003; Makekadyrova, 2008; Senova, 2011). Other authors focus on the characteristics of the territorial characterisation of tourism based on the linkage of tourism and recreational resources to a specific territory. There are many different characteristics in relation to which spatial forms of tourism are formed. Let's consider some of them:

Territorial and recreational complex being a combination of recreational institutions and associated infrastructure enterprises, united by close production and economic ties, as well as the joint use of the geographical location, natural and economic resources of the territory occupied by the complex (Kotlyarov, 1978).

Tourism complex is a closed network of facilities designed to serve tourists and consists of accommodation (hotels, 
motels, etc.), catering (restaurants, cafes, bars, etc.), related services (equipped beaches, viewpoints and sports grounds, stadiums, swimming pools, cabarets, cinemas, etc.) (Kalashova, 2009). A number of studies by domestic authors are devoted to the tourism complex: (Davydenko, 2006; Dmytrenko, 2008).

Tourism industry is characterised by a dependence on the presence and functioning of enterprises and organisations from various economic sectors, which are involved to varying degrees in the tourism offer. In order for tourism offer to emerge, tourism resources must be available, in addition, demand for a particular tourism resource must be generated, activities for the formation of the tourism product must be regulated and stimulated, and the tourism product must be effectively marketed. We believe that in order to consider tourism complexes, a number of attributes should be taken into account.

First, it is a territorial-administrative attribute, according to which tourism complexes are allocated within a particular region (constituent entities of Ukraine). In this case, it should be noted that they have already existed and the main work should be done to improve their efficient functioning. Such tourism complexes have specific tourism resources, infrastructure, institutional conditions and other characteristics. The second attribute is the taxonomic rank, on the basis of which recreational touristic zones, tourist-recreational districts and special economic tourist-recreational zones are distinguished. Tourist-recreational zones are allocated within geographical areas with similar tourism resources; territorial zoning provides for the allocation of a certain complex within a tourist-recreational zone, and a special economic touristrecreational zone requires special attention, the types of activities within it are regulated administratively.

The third attribute is structural distribution, it divides tourism complexes according to the focus of tourism in a region into different types, subspecies and varieties of tourism. The classification of tourism complexes is represented by a structural and graphic model shown in Figure 2. Regional tourism resources reflect the development potential and capacity of a particular area of the region and are often limited, while the ability of a region to meet the needs of tourists is determined precisely by the composition and condition of the resources and factors for tourism development in the area.

Kalashova (2009), Koblova (2005), Bogomolova (2008), Shapovalova (2006) in their definitions pay attention to such characteristic of the tourism sector as development management at the regional and local levels.

Territorial and recreational complex is a combination of recreational institutions and associated infrastructure enterprises, united by close production and economic ties, as well as the joint use of the geographical location, natural and economic resources of the territory occupied by the complex (Kotlyarov, 1978).

Territorial recreational system (TRS) is one of intersectoral varieties of socioeconomic geosystems. The concept of TRS was introduced by the economistgeographer V.S. Preobrazhensky (1971) in the 60s of the twentieth century; he justified it as the main form of territorial organisation of recreational economy. He understood TRS as "a social geographical system consisting of interconnected subsystems: natural and cultural structures, service personnel, management body and, finally, recreationists, which is characterised by both functional integrity (the state of

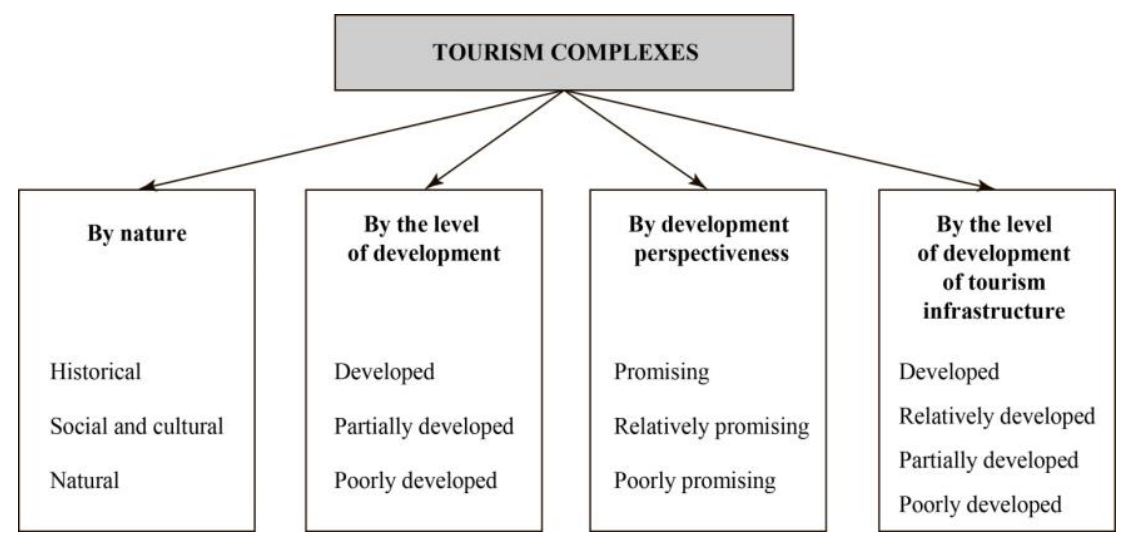

Figure 2. Classification of tourism complexes (Source: ordered by the authors) subsystems is determined by the social function of the system as a whole) and territoriality" (Preobrazhensky and Vedenin, 1971). In considering TRS, he distinguished between demographic and resource-graphic systems that differ according to the principles of territorial organisation: in the first case, the "territorial differentiation of recreational needs" forms the basis, while in the second, the availability of specific defined resources (Chudnovsky and Zhukova, 2002).

The main priorities in the study of TRS included: the structure, functioning, management, placement of industrial (in this case recreational) facilities in a certain territory. The interaction of these territorial entities with other functional systems, with other territories, were not given much importance due to the development and application of these theories during the period of planned (administrative-command) economy. In practice, TRS were closed systems with highly saturated internal ties within the system and virtually without any external connections.

The concept of TRS has gradually been replaced by that of the tourism and recreation complex. Modern economic literature traditionally considers the concept of tourism complex as a set of elements such as accommodation, catering facilities, transportation, cognitive, entertainment, business, recreational, sports and other purposes, including organisations providing sightseeing services and guide-translator services (Chudnovsky and Zhukova, 2002). Although the concept is often used in the academic literature, there is currently no consensus on its meaning. There is a divergence of views both in terms of understanding the essence of the tourism complex and in relation to the composition of the sectors and enterprises included in it. Thus, (Baeva, 2008a) considers it a complex institutional socio-economic and material formation, with the main backbone factor being the provision of human vitality through prevention, treatment, rehabilitation, mass recreation, recreation, and resulting in the creation and consumption of a specific tourism and recreational product as the initial basis for the formation and implementation of a high-quality package of health and recreational services in the functioning of an integrated sanatorium and health resort. The same problem is also explored by Koblova (2005), Vasylykha et al., 2017. 
Resort and tourism complex is a set of interrelated industries that ensure the reproduction (production, distribution, exchange and consumption) of the whole range of resort and tourism services in all their modern diversity (Beydyk, 1997). In a narrow sense, these are sanatoriums, hotels, tourist complexes, holiday centres, youth camps, campgrounds and other recreational facilities, fixed and circulating assets, and human resources that are involved in serving tourists. In a broad sense, it is the totality of closely interrelated industries serving the resort and tourism complex, as considered in a narrow sense (Sharafutdinov, 2000). Abramova (2004) considers it to be the totality of all enterprises and industries covered by the notion "tourism industry of a country" that are located in the territory of resorts, spa regions or health resort areas.

The most common interpretation of the term 'recreational areas' is to understand them as separate areas or zones that are prepared in a certain way for mass recreation and recreation of the population and are served by qualified personnel. In particular, the Dictionary of Ecology defines a recreational area as an area used for recreation, mass recreation, tourism and excursions (Musienko, 2004). Pashentseva (2011) defines recreational areas as a single natural complex located within a recreational and health-improving landscape that is used by subjects of recreational and other economic activities for medical, recreational and cultural purposes, provided that its natural state is preserved. Fomenko (2007: 309) considers the notion of "recreational area" as an area used for human recreation, mass recreation, tourism and excursions.

Recreational complex it is a set of industries and types of economic activities that provide recreational services to the population of a country, region, or city and create the necessary prerequisites for the normal functioning of the recreational and tourism economy. Certainly, recreational complexes ensure the functioning of weekly, monthly, seasonal recreational cycles, but in individual cases (city, industrial hub, industrial district) the problems of organising short-term recreation - on a weekly and daily basis - should also be emphasised (Baeva, 2008b).

Recreational area is a territory suitable for organizing recreation and tourism due to the availability of recreational resources of a natural or anthropogenic nature (Halachieva, 2006).

Tourist and recreational area is a territory formed by tourism and recreational demand with tourist and recreational resources and conditions, as well as the necessary degree of development of tourism and recreational infrastructure (Dzhadzhuhazova, 2005). The theoretical background of regional clusters includes: the definition of regional clusters (European Commission, 2002; Delgado et al., 2015; Iordache et al., 2010; Bathelt et al., 2004), formation of regional clusters, which is subject to the principle of localization (Belleflamme et al., 2000, 161), agglomeration (Rosenthal and Strange, 2004), geographical concentration of industries in regional clusters (Weber,1929 and Marshall, 1920), investment production and new entrepreneurial activity, demonstrating a higher level of cooperation and competition than can be found among dispersed firms (Enright, 2001). Currently, researchers increasingly use the notion of "cluster" for characterizing the tourism development in a particular territory. Territorial and industry orientation to the use of clusters at the regional level was first applied by Porter (2011). Cluster is a set of interrelated homogeneous elements, the combination of which acts as an independent unit with certain properties. Tourist and recreational cluster is a territory formed by tourism and recreational demand with tourist and recreational resources and conditions, as well as the necessary degree of development of tourism and recreational infrastructure (Boyko, 2011).

Using the term "cluster" today, various facilities cha be described, for example: a conglomerate that specializes in the production of the same type of products, united within a certain geographical space; an economic sector represented by enterprises located in the same territory; companies that form the added value of a certain standard. The most important result of combining various enterprises and organizations into a cluster is increasing performance and labor productivity not only within the framework of enterprises included into a cluster, but also in those areas of economic activity that are somehow connected with it through joint activities, that is, this activity allows you to achieve a synergistic effect. Thus, the cluster approach creates a greater potential for the development of the structures included into it.

Currently, the development of cluster initiatives in the regions of Ukraine is relevant. Currently, many researchers note that cluster structures are an optimal form of arrangement of modern tourism services both at the national level and at the level of a particular region (Hanushchak-Efimenko, 2010; Fedorets, 2011). Works are devoted to the problems of forming regional cluster structures in the tourism industry (Hanushchak-Efimenko, 2010; Kraynyk, 2009). It shall be noted that typologization of regional tourism clusters is far from an easy process. The complexity of such typologization follows, on the one hand, from the very definition of a cluster as a set of companies and business structures located in the same territory (while a cluster includes not only pure travel companies, but also facilities of tourism infrastructure, hotels and public catering enterprises (Hanushchak-Efimenko, 2010; Kraynyk, 2009), on the other hand, from the geographical diversity of the regions of Ukraine, which causes significant differences in their "tourism specialization". Now the regions have different priorities in the development of a particular type of tourism (historical and educational, business, gastronomic, health, beach, eco-tourism, etc.), which affect the type of regional tourism cluster. Recently, when identifying tourism clusters, more preference is given to geographical criteria than to structural and economic ones.

In particular, according to geographical criteria clusters are classified into:

- longitudinal - elements of clusters of this type are located or elongated along a specific resource, which is clearly displayed on the basis of physical and geographical zoning. For example, beach resorts in the cities are concentrated on the coast of a sea or an ocean and are also a center for tourists in the cluster;

- monocentric - characterized by the presence of a pronounced "center of tourist flows", through which tourists arrive in the cluster. The center contains the main elements of tourist infrastructure, which provide other (peripheral) elements. A pronounced cluster center can be defined as a "cluster core" (similar to industrial and agro-industrial clusters);

- polycentric - characterized by the presence of several centers of tourist flows connected by elements of transport infrastructure and located in close geographical proximity to each other; 
- dispersed or uniform - characterized by the presence of elements that are evenly dispersed through the territory of the cluster (equivalent cities and resorts of interest to tourists) (Porter, 2011).

The typology based on geographical characteristics can be expanded by other criteria, in particular, the location of the administrative center within the tourism cluster, determination of the territorial boundaries of the cluster, density of the main objects of the cluster, etc. (Enright, 1996).

Structural, economic and social criteria (criteria for economic and social efficiency) are also of great importance for identifying the types of regional tourism clusters, in addition to geographical ones.

An important difference between tourism clusters is the availability of a "framed" or "frameless" ("diffusion") structure. A tourism cluster is, first of all, a community of various enterprises and organizations within a certain territory that are directly or indirectly related to the provision of tourist services. It is quite difficult to subordinate the boundaries of a tourism cluster to standard industry classification systems. A tourism cluster should consist of a combination of industries that create a tourism product and conditions for increasing its competitiveness (Fedorets, 2011).

Attention should be paid to the following circumstances and significant characteristics of tourism clustering. Thus, any tourism cluster is always based on the humanitarian component, since all tourism services are always focused on the consumer and their interests, and are weakly dependent on the policy of the state and individual regions in terms of regulating the tourism sector. Unlike an industrial cluster, a tourism cluster always exists only when four components of the complex are available: "resource - consumer - producer - seller of tourist products and services", the loss of one of the elements will sharply reduce the degree of efficiency and competitiveness of the cluster and other territorial entity. If industrial clusters are essentially territorial, and their effectiveness is determined by the mutual proximity of enterprises, then tourism clusters are created as extraterritorial formations - based on the specific specialization, resource capabilities of the territory, as well as the existing needs of tourists. Tourism clusters are characterized in their creation by the approach called "from resources" and "from needs", which contradicts the position of the classical theory of TRS by Preobrazhensky (1971), which was proposed back in the 60s of the twentieth century, while industrial clusters are created "from the territory".

The uniqueness of a tourism cluster lies in the complexity of what it produces and sells - of a tourism product (a comprehensive tourism service). If under the operation of industrial cluster enterprises the final product is most often created, then for a tourism cluster, the final product is only designed and formed by a special group of tourism enterprises tour operators, and then sold to end users - travel agents. This requires specific approaches to the design and formation of tourism clusters, taking into account the methodology of marketing, positioning and promotion of tourism opportunities and organizations of individual regions, in general, and specific tourism clusters, in particular.

Tourism clusters have a number of characteristics that distinguish them from other types of clusters, in particular:

- use of tourism and recreational resources, including natural, cultural, historical and socio-economic resources used for the formation of a tourism product and the production of tourism services;

- unlike other types of clusters, when designing and creating, tourism clusters are not linked to the administrative borders of regions. They can immediately include the territories of several administrative divisions of the country;

- a necessary element of a tourism cluster is the tourism infrastructure, the elements of which are located not only in the territory of the cluster, but also in the territory of neighboring regions and even countries - in order to ensure the availability of tourism products and services offered by the cluster;

- given that the main element of any cluster is the consumer preferences of tourists, the cluster should offer a variety of tourism products and services provided at different prices;

- the catalyst and regulator of all relations and processes related to the design, creation and development of tourism clusters are state and management authorities at the national and regional levels, and local self-government bodies (local administrations);

- the specifics of tourism clusters are determined by the peculiarities of their territorial construction, since any such cluster must combine three ways of territorial arrangement of tourism potential - linear (touristic routes), planar (touristic districts and cities) and point (touristic centers);

- the development of tourism clusters directly depends on the infrastructure and resource sectors, while the innovation component and synergistic effect achieved through the functional integration of industries and enterprises are of secondary importance for the development of the cluster;

- the effectiveness of a tourism cluster is determined only at the level of development of inbound and especially domestic tourism, which makes the cluster development of touristic territories significantly dependent on a competent and effective business strategy, as well as on the implementation of a set of marketing and advertising strategies aimed at promoting the cluster.

Creation of a tourism cluster is aimed at addressing labor-intensive tasks of combining the efforts of entrepreneurs, business structures and the state. Well-functioning clusters are no longer hierarchical networks and are transformed into a structure of mobile relationships between households, companies, and institutions. These relationships are based on a permanent basis, they can shift and expand into related types of economic activity. Therefore, a "cluster " can be of two forms: gastronomic and territorial. A cluster occurs in a particular location due to specific historical or geographical reasons, the value of which can be reduced to zero over time (when the cluster itself becomes powerful and is selfsupported competitively). The development of the regional gastronomic cluster of the Right-Bank Polissia of Ukraine leads to strengthening the competitive advantages of participants by forming a gastronomic hub, which improves the quality of interaction of enterprises involved in the production of tourism products, and acts as a consolidator.

In a territorial cluster, enterprises interact, as a rule, on the basis of competitive partnership relations in order to achieve a common goal - the development of the entire territory as a cluster; enterprises may belong to one or more types of economic activity (Tyshchenko, 2019). The authors found the following primary characteristics of a regional gastronomic 
cluster of the Right-Bank Polissia of Ukraine: an unusually wide composition of participants; the presence of a synergetic effect; a higher level of productivity and wages; flexibility and dynamism of functioning; a higher level of information exchange and innovation; competing enterprises (companies) cooperate in order to realize the potential of the territory and its competitive advantages, etc. Several large economic entities constituting the "core of the cluster" create a geographically concentrated demand for monotonous components, laborers of appropriate qualifications, and services of certain orientation. Related and supporting enterprises get the opportunity to meet high demand from the "core of the cluster", save on sales and transportation costs. The ordered structure of the regional gastronomic cluster of the Right-Bank Polissia of Ukraine is presented in the form of functional blocks (nodes) (Figure 3).

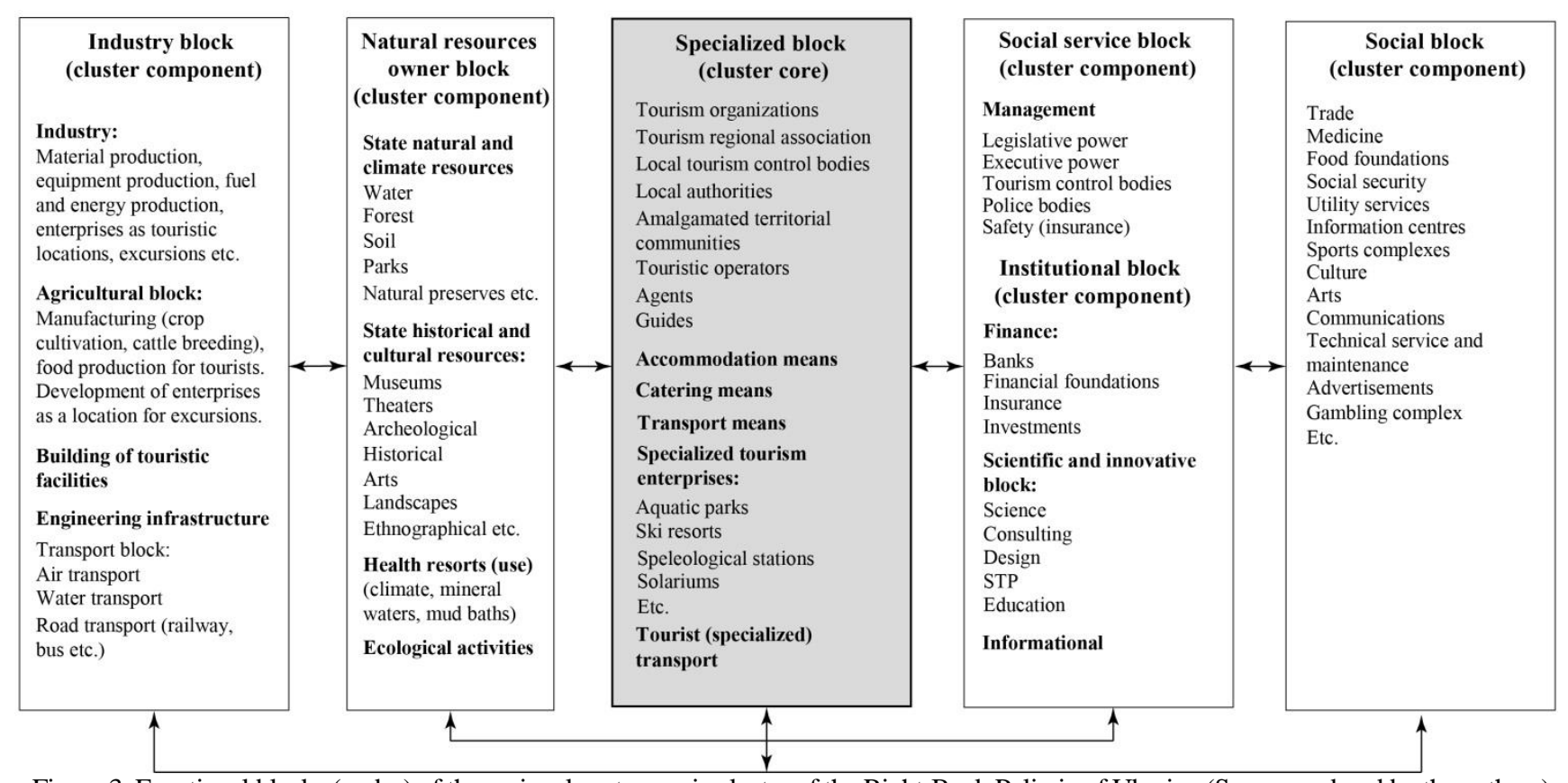

Figure 3. Functional blocks (nodes) of the regional gastronomic cluster of the Right-Bank Polissia of Ukraine (Source: ordered by the authors)

1. Idea and program for the development of gastronomic tourism cluster

\section{$\downarrow$}

2. Search for destination, routes, and their assessment

3. Marketing researches for the food feasibility

4. Development of food

5. Establishing the volume of the gastronomic cluster

6. Attraction of tourism resources

7. Creation of the tourism enterprise network

\section{$\checkmark$}

8. Launch

Figure 4. Life cycle of a regional tourism cluster (Source: adapted by the authors according to the strategy for the development of gastronomic tourism in the Right-Bank Polissia of Ukraine)
In our opinion, the gastronomic clusters of the Right-Bank Polissia of Ukraine are limited by the life cycle, as basically all types of clusters which begin with the formation of a new idea, and end with the launch, implementation and approval of a new tourism product on the market. The life cycle of a tourism cluster is represented by typical phases characterised by specific activities, results obtained and decisions made, see Figure 4. This cluster has a complex internal structure comprising a multitude of economic agents, consisting of main enterprises producing and selling tourism products, auxiliary (related) industries, as well as educational institutions and research organisations. Participants in a regional gastronomic cluster tend to be included in deep technological cooperation among themselves on the basis of their participation in valueadded chains and value accumulation systems. Alignment of a particular activity together with another one forms intra-firm value chains. To achieve competitive advantage, a business needs to optimise its own value chain, as well as the external value chain that will connect it with suppliers and consumers. A dynamically developed cluster covers many different value creation chains that form a system of value accumulation. The main challenge here is to establish complete value chains through established structures and to prevent the leakage of created value from the region. The formation and development of clusters is one of the important factors in a sustainable business development strategy in the region. In our case, the main task is to determine the purpose of its development in the long run, as short-term and medium-term prospects are spelled out in the regional development programs of each region. It should be noted that not one of the tourist regions of Ukraine does not meet the quality characteristics that would fully satisfy the consumer services of the region or cluster.

Such countries as Bulgaria and Turkey with its Black Sea coast (relative to the southern region Ukraine), Eastern Poland, Slovakia are more attractive for tourists and every year the preferences of domestic tourists are given to rest abroad instead of rest in the Azov-Black Sea coast or in the Ukrainian part of the Carpathians. If we consider the Right-Bank 
Polissia of Ukraine as a tourist destination, one can see that the tourist direction here was given more point than complex attention. The same happens with tourism products in the regional tourism market. The tourism market and service companies and industries offer different products, but tourism products are heterogeneous: they are complex and consist of a large number of additional components provided by suppliers from different public and private sectors. The process of buying and consuming a tourist product extends over time and distance (Kachniewska, 2006). Regional tourism resources open up prospects for organizing tourism and recreation clusters. Despite the fact that the composition of tourism resources of the Right-bank Polissia is very diverse and appropriately unevenly placed, we believe that it is worth separating gastronomic tourism clusters, where there is a concentration of tourism resources and gastronomic potential. It will allow us to create an optimal model of gastronomic tourism, which will spin on the practice of nomadism, simulacrum, escapism. The reset of gastronomic tours (Nesterchuk et al., 2021) is possible only if the tourism gastronomic potential of the Right-Bank Polissia is justified, which is the basis for creating clusters for the development of gastronomic tourism in the Right-Bank Polissia.

We are used to classical interpretations of cluster as its identification by industry attribute. Currently, there is a fairly broad classification of clusters according to the criterion of industry, based on which the following types of clusters can be distinguished: textile, machine building, pharmaceuticals, petrochemical, tourism, etc. There are also inter-sectoral clusters (industrial, agrarian, transport and logistics), event clusters, etc. (Sharafutdinov, 2000; Golik and Maksimova, 2013). However, it should be noted that industry-specific identification is largely determined by the structural characteristics of the cluster, primarily by the presence or absence of its core. The presence of a cluster core makes it easier to identify the cluster by its industry attribute, while the absence of the core makes it more difficult, as the core is most often a large system of constituent enterprises of the dominant industry, and determines the industry profile of the cluster. The complexity of structural identification is also determined by the presence of "unexpressed" clusters or clusters at the stage of formation or decay. In particular, in accordance with the approach of Enright (2000) the following cluster types can be distinguished:

- operational cluster is a group of companies that function as a single system. The main characteristics of the operational cluster are a developed social infrastructure, rapid exchange of innovations, dynamic growth, a wellcoordinated production process system, and high potential. Examples of working clusters: the electronics industry cluster in Silicon Valley (California, USA), the knitting industry cluster (North Carolina, USA), the flower cluster (Netherlands).

- latent cluster is an industrial agglomerate that has the potential to develop into an operational cluster. Certain shortcomings in national legislation prevent a latent cluster turn into an operational one, primarily due to the lack of laws aimed at supporting cluster entities and optimizing the investment and tax climate in the regions. Enterprises cannot build a single system in which they could interact with other elements of the cluster

- potential cluster is a group of companies that has certain characteristics of an operational cluster, but it lacks important components of the latter, such as stable business relations between cluster participants and the development of a competitive environment. Examples of potential clusters: the software cluster (Oregon, USA), the aerospace cluster (Arizona, USA). Regional cluster (Enright, 2000) is a geographical agglomeration of firms operating in related sectors of the economy. A regional cluster may include: 1 - an industrial area of small and medium-sized enterprises; 2 - a concentration of high-tech firms connected through the development and use of common production methods (technologies); 3 - a production system with former enterprises of large TNSes and firms that "broke away" from the parent companies as a result of the spin-off process. Competitive advantages are created not at the supranational or national level, but at the regional level, where the main role is played by the historical prerequisites for regional development, the diversity of business cultures, the organization of production and education. The most successful model for the development of gastronomic tourism is the projected gastronomic tourism cluster of the Right-Bank Polissia of Ukraine.

The foreseeable gastronomic tourism cluster is a geographical hub, regionally labelled, the prerequisites of which are the tourism potential of the territory, autochthonous gastronomy, tourism business and related gastronomic products, services, events, tours, gastronomic tourism products, cross-cultural communication, national specificity of business and education necessary to meet the demand for a specific gastronomic product and promote the products and traditions of the region through organized production, wholesale and retail trade and tourism.

The scientific world relies on the opinion of Porter (2011) and Enright (1996), which highlights the following reasons for the need to stimulate cluster development: increased labor productivity and production efficiency (skilled labor, Information, service, educational center). Firms gather to coordinate, transact, thereby increasing the diffusion of innovation and comparing the performance of rival firms; stimulate innovation through access to up-to-date information, cooperation with research centres; at a high level, the commercialisation of knowledge and production encourages the creation of new firms, the launch of new product types, increasing information flows, sharing ideas, knowledge, know-how in mid-staff. The driving force behind the cluster development is the rhombus of competitive advantages, and a spatial entity such as a regional and industrial cluster is a reflection in reality of this rhombus. In practice, clusters are understood as a group of business enterprises and non-entrepreneurial organisations whose membership is an important element of the individual competitiveness of each member firm. Clusters combine 'buyer-supplier relationships, either shared technology, shared buyers or distribution channels or shared pools of labour' (Enright, 1996:191). It is also important to note that a cluster involves a certain degree of spatial proximity between its players. Geographical proximity allows for face-to-face interactions, common labour markets and dissemination of knowledge, especially "tacit" knowledge that is difficult to codify. The advantage of a separate regional cluster may over time be some flexibility in the structure of the firm and coordination of transactions, it can progress along with changes in technology, tastes, corporate strategy and competition environment. It can show a higher level of cooperation and competition than among scattered firms. A regional cluster can benefit from the presence of foreign multinational companies, which in turn can benefit from a presence in regional clusters (Enright, 2002). 
According to (Feser et al., 2008), there are generally two different types of cluster policies. First, policy applications that focus specifically on identified clusters are called 'cluster-specific strategies'. According to the cluster policy approach, the goal is to encourage the emergence or development of a separate identified cluster. The first step in this policy approach is to create a cluster and determine its characteristics and nature using SWOT-analysis. The main characteristic of the cluster approach is a comprehensive attempt to develop a specific value chain through a series of carefully designed supply and demand policy interventions. Cluster approaches are mutually reinforcing and may include economic interventions that are not development strategies per se, but instead are traditional functions of governments (e.g. regulation, provision, pricing and education). The second approach is referred to as "cluster-informed strategies". The main policy goal from a cluster perspective is the improved implementation of individual development initiatives. This approach to cluster development is less holistic than the cluster approach itself. By this approach, no formalisation of cluster mapping is applied, but some cluster-related methods can be applied. For example, this approach can be aimed at exploring parts of the cluster supply chain (for example, weaknesses of local suppliers), which will then be directed towards business development initiatives. According to this approach, clusters are primarily considered as an analytical device for improving the effectiveness of narrower types of policy tools (Feser et al., 2008).

Contribution by M. Enright's contribution to cluster theory is that he identified four types of cluster policy depending on the nature of state "intervention": catalytic - the state only brings stakeholders together and provides them with little support; supportive - catalytic policy is complemented by investment in infrastructure, education, vocational training, thereby providing an enabling environment for cluster development; directive - supportive policy using the cluster programme to transform the local economic structure or the availability of National targeted programs; interventionist policy with active use of subsidies, incentives, protection and regulation, significant presence in the cluster and control over the activities of its participants (Enright, 2000: 15). M. Enright emphasised the role of regional and spatial aspects in generating the driving forces that underpin competitiveness. The scholar, focusing on the globalisation-localisation paradox, argued that the globalisation of competition is entirely consistent with the localisation of competitive advantage in certain industry sectors and activities. Consequently, those who study successful innovative high-tech clusters tend to focus on localisation preferences and the possibility of globalisation (Competitive Regional Clusters, 2007).

Development of the projected gastronomic tourism clusters of the Right-Bank Polissia of Ukraine envisages the typification of territories for improving opportunities to promote products and traditions of the region through integrated forms and methods of production activities, trade, as well as tourism in the short, medium and long term.

When selecting such territories on the map model (Figure 5), indicators of gastronomic potential of physiographic districts calculated in the author's work (Nesterchuk et al., 2021), extended by indicators of tourist flows to respective territories and the number of persons employed in gastronomic tourism (these indicators are listed from the units of administrative-territorial structure, for which they are recorded by the statistical service) were used. When calculating the gastronomic potential of a physiographic region (in points) for bringing the different types of indicators into a unified system, each structural component of the map-diagram was given a weighting coefficient.

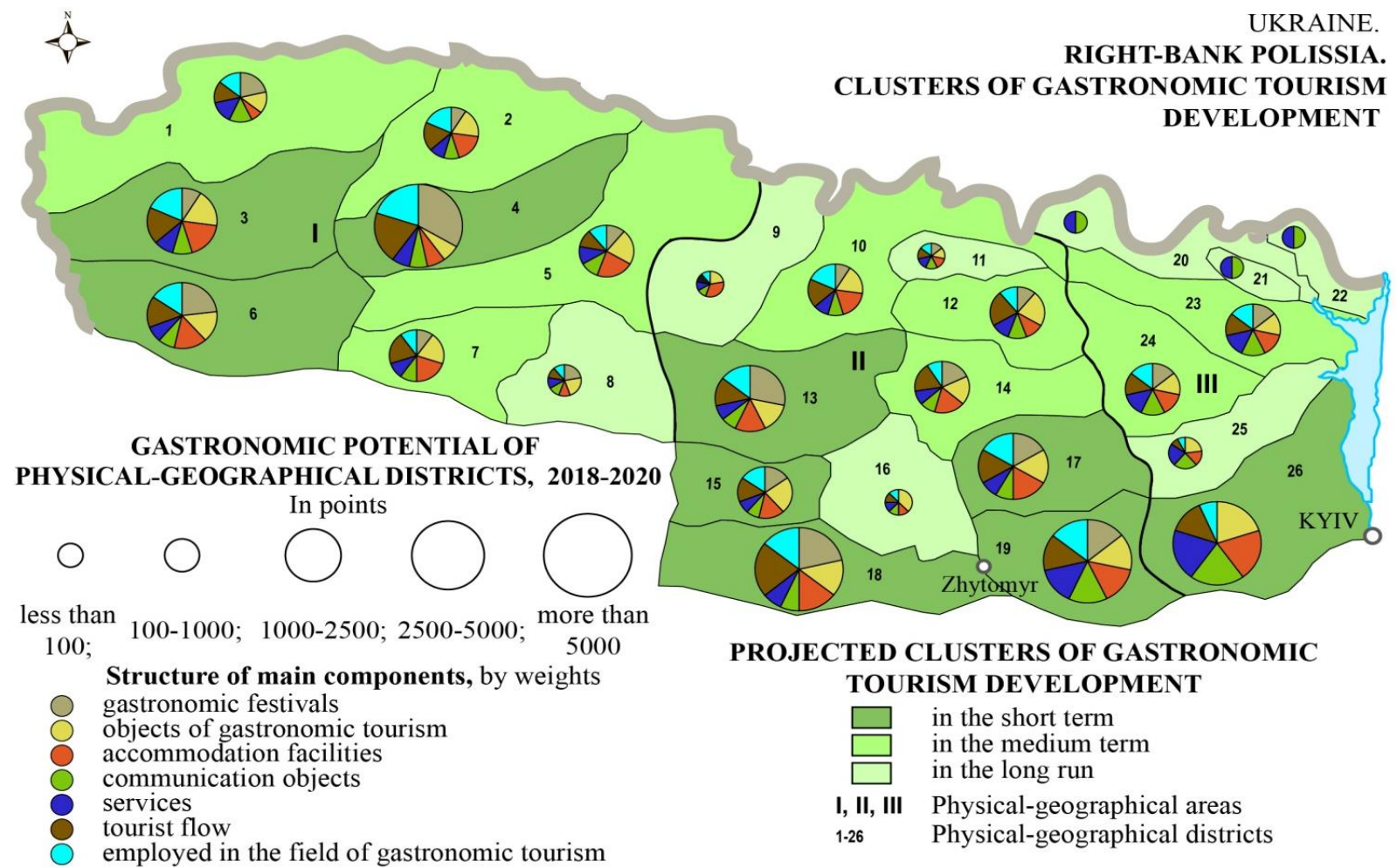

Scale $1: 3500000$

Figure 5. Clusters of gastronomic tourism development in the Right-Bank Polissia of Ukraine (Source: author's development, original copy presented on a scale of 1:3 500 000) 
The predicted three clusters of gastronomic tourism development in the Right-Bank Polissia by physical and geographical areas (as mapping units) are shown using the quantitative background method, which are the numerical values of the term of cluster formation. In the short term, the most powerful development will be in the Lyuboml-Kovel, TuriyskRozhishe, Manevychy-Volodymyrets physical and geographical areas of the Volyn Polissia region, HorodnytsiaEmilchyne, Korets-Novograd-Volynsky, Irshansk-Malin, Baranivka-Vysoka Pich, Chernyakhivka-Korostyshev regions of Zhytomyr Polissia region, Zdvyzh-Irpin regions of Kyiv Polissia regions. This indicates a score of gastronomic potential from 2500-5000 and over 5000 points in physical and geographical areas. The structure of the main components is dominated by segments: gastronomic festivals, tourist flows, the number of employed in the field of gastronomic tourism.

In the medium term, the projected clusters of gastronomic tourism development in the Right-Bank Polissia will develop in Verkhnopripyatsky, Nizhnostyrsky, Kolkiv-Sarny, Kivertsi-Tsuman in the physical and geographical areas of the Volyn Polissia region; Olevsky-Belokorovitsky, Norynsk-Zherivsk, Korosten-Chopovychy regions of Zhytomyr Polissia region, Nizhniouzky, Narodychy-Ivankiv regions of Kyiv Polissia region. Confirmation is the calculated score of gastronomic potential from 1000-2500 points in physical and geographical areas. The structure of the main components is dominated by the following segments: gastronomy festivals, gastronomy tourism facilities, stable tourist flows, number of people employed in gastronomy tourism, almost equal indicators of tourist accommodation facilities and services.

In the long term, the projected clusters of gastronomic tourism development in the Right-Bank Polissia may develop in the physical and geographical areas of the Kostopol-Bereznov region of Volyn Polissia, Klivsky-Rokitnyansky, Slovechansky-Ovruchsky, Dovbyshsko-Chervonoarmiysky regions of Zhytomyr Polissia regions, Rudnyansky-Vilchansky, Chistohalivsky-Korohodsky, Nizhnioprypyatsky, Nizhnioteterivsky regions of Kyiv Polissia, where the gastronomic potential score is from 100-1000 and under 100 points in physical and geographical areas. There are minor segments in the structure of the main components: gastronomy festivals, gastronomy tourism facilities, tourist flows, number of employed in gastronomy tourism, and communication facilities and services presented only in some points.

To ensure spatial planning of the projected clusters of gastronomic tourism development in the RightBank Polissia of Ukraine, it is proposed to distinguish and link its functional and industry complexes. The latter can be justified on the basis of the correspondence of functional complexes to different territorial zones. The concept of purposeful cluster formation is based on the creation of United territorial communities (UTC) of tourism business associations at the regional level based on the creation of its management structure: Figure 6.

In our opinion, the proposed model is a combination of five main complexes and their blocks. The core of the cluster is a (specialized) tourism complex. It includes organizations and individuals directly related to tourism activities, production of tourism services and service rendering (tour operators and travel agents, sanatoriums, ski complexes, etc.). In the center of the cluster core is the consumer of the tourism product, on which the functioning of the cluster depends at a particular time. As well, the central elements of the cluster are enterprises that provide accommodation, food, entertainment and touristic transport services. In addition, this complex interacts with potential

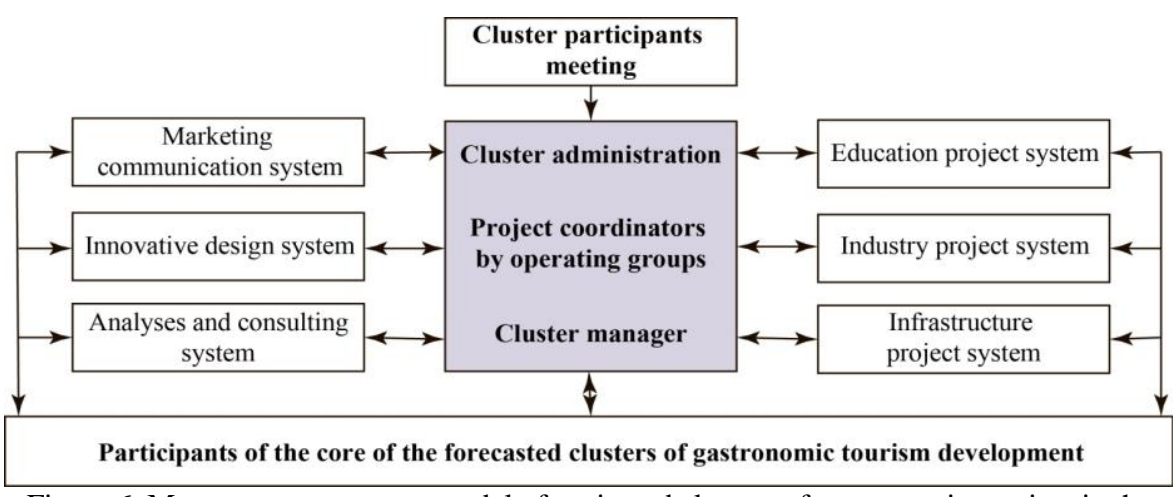

Figure 6. Management structure model of projected clusters of gastronomic tourism in the Right-Bank Polissia of Ukraine (Source: ordered by the authors)

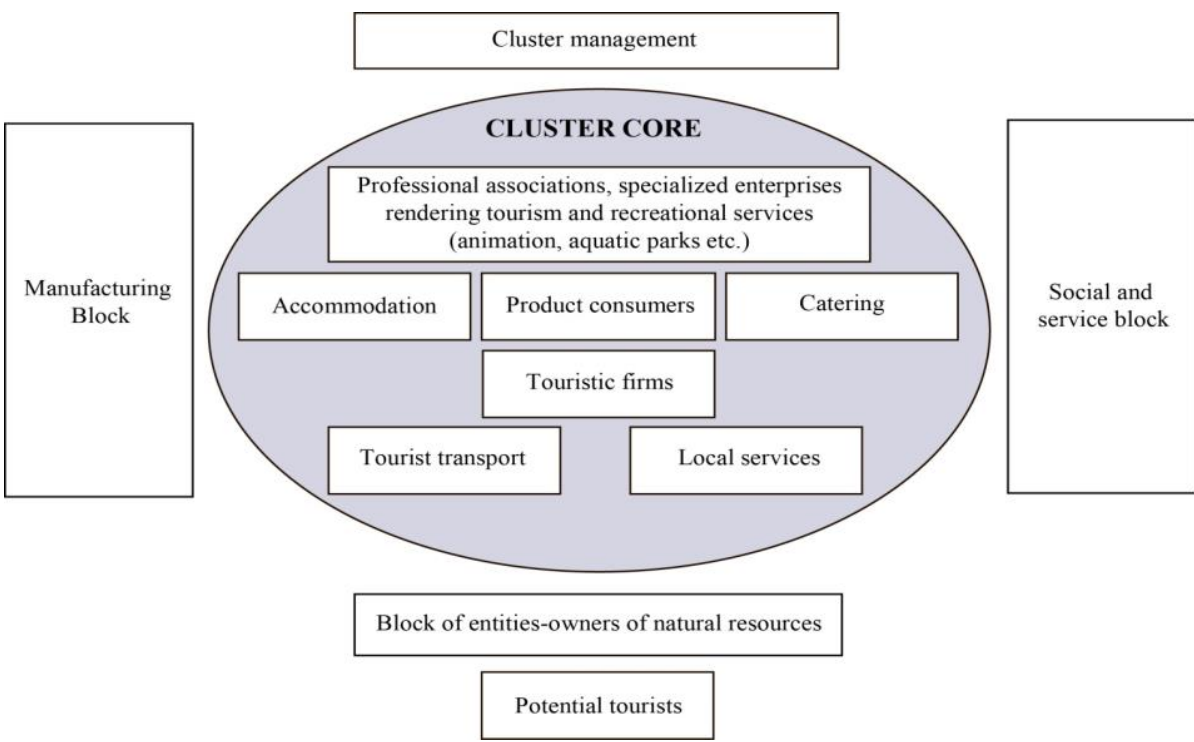

Figure 7. Diagram of the functional structure of the projected gastronomic cluster of the Right-bank Polissia of Ukraine (Source: ordered by the authors)

tourists (their needs are investigated, marketing activities are conducted, etc.). For the cluster to function properly, there must be a body that coordinates its work (Figure 7). All other subjects of the cluster are represented by four complexes: service-system-forming (management bodies, training personnel, finance, etc.); production (providing food, goods, 
equipment and construction materials); social-service (cultural and sports institutions, trade, medical institutions, consumer services, etc.); complex of natural resources and conditions, including organizations that own natural resources (Figure 7).

\section{CONCLUSION}

The considered signs of formation of spatial forms of tourism testified that the most optimal (most successful) modern form, which will ensure the development of gastronomic tourism at the regional level, are clusters, which are substantiated for the Ukrainian Right-Bank Polissia as potential. Prerequisites for the creation of these forms are mosaic landscapes, cultural and historical artifacts, the diverse composition of tourist resources of the study area, the concentration of tourist resources and gastronomic potential, which allowed to justify the directions of their creation.

The formation of the projected gastronomic clusters of the Right-Bank Polissia of Ukraine will be based on the author's model, in particular, the functional structure, which will provide an opportunity to coordinate the work of its main complexes. The development of projected gastronomic tourism clusters of the Right-Bank Polissia of Ukraine also involves typification of territories to improve the promotion of products and traditions of the region through integrated forms and methods of production, trade and tourism in the short, medium and long term.

The authors identified the features of the regional gastronomic cluster of the Right-Bank Polissia of Ukraine, which include an unusually wide range of participants, have a synergistic effect and higher productivity and wages, flexibility and dynamism, higher level of information exchange and innovation, and competing firms cooperate to realization of the potential of the territory and its competitive advantages. Gastronomic clusters of the Right-Bank Polissia of Ukraine are limited to typical specialties of the life cycle (in terms of activities, results and decisions), which begins with the formation of a new idea and ends with the introduction of a new tourism product on the market, its implementation and approval.

The cartographic method made it possible to visualize the cluster model of the development of gastronomic tourism of the Right-Bank Polissia of Ukraine and influenced the possibilities of determining its managerial and functional structure. The projected gastronomic clusters of the Right-Bank Polissia of Ukraine may be weak in meeting the expectations of modern tourism, so they need an innovative approach to their implementation, in particular, the optimal use of its tourism potential. This allows for enhanced cooperation and competition between different actors. On the basis of substantiated clusters further scientific researches can be directed on carrying out gastronomic and tourist zoning of the territory of the Right-Bank Polissia of Ukraine on the basis of synthesis of operational units within physical and geographical regions.

\section{Acknowledgements}

The authors are grateful to Doctor of Economics, Professor V. Tarasova for her thoughtful suggestions and comments. We also want to express words of gratitude to our colleagues at the department for the corrections and constructive comments they have made.

\section{REFERENCES}

Abramova, T. (2004). Osnovy i mekhanizm upravlinnia rozvytkom kurortno-turystskoho kompleksu Rosii [Fundamentals and mechanism for managing the development of the resort and tourist complex of Russia]. Dissertation of the Candidate of Economic Sciences. 174 Moscow, Russia.

Baeva, O. (2008a). Organizational and economic principles of management of tourist and recreational complexes. Industry of hospitality in European countries, 14-16, Publishing Center of the Crimean Institute of Business, Ukraine.

Baeva, O. (2008b). Orhanizatsiino-ekonomichni zasady upravlinnia turystychno-rekreatsiinymy kompleksamy [Organizational and economic principles of management of tourist and recreational complexes]. In the book: Industriya gostepriimstva v stranah Evropy [Industry of hospitality in European countries (pp.14-16)]. Publishing Center of the Crimean Institute of Business, Ukraine.

Bathelt, H., Malmberg, A., \& Maskell, P. (2004). Clusters and knowledge: local buzz, global pipelines and the process of knowledge creation. Progress in human geography, 28 (1), 31-56.

Belleflamme, P., Picard, P., \& Thisse, J. (2000). An Economic Theory of Regional Clusters. Journal of Urban Economics, 48, $158-184$.

Beydyk, O. (1997). Slovnyk-dovidnyk $z$ heohrafii turyzmu, rekrealohii ta rekreatsiinoi heohrafii [Dictionary-reference book on the geography of tourism, recreation and recreational geography]. Palette, Ukraine.

Bogomolova, E. (2008). Teoretiko-metodologicheskie osnovy upravleniya razvitiem turistsko-rekreacionnogo kompleksa regiona [Theoretical and methodological foundations for managing the development of the tourist and recreational complex of the region]. Dis. Doctor of Economic Sciences, Maikop, Russia.

Boyko, A. (2011). Formirovanie klasterov kak instrument povysheniya konkurentosposobnosti turistskih uslug [Formation of clusters as a tool for increasing the competitiveness of tourist services]. Author's abstract. Dissertation of the Candidate of Economic Sciences. Novosibirsk, Russia.

Chudnovsky, A., \& Zhukova, M. (2002). Menedzhment turizma [Tourism management]. Finance and statistics, Russia.

Davydenko, L. (2006). Derzhavne rehuliuvannia sfery turyzmu na oblasnomu rivni [State regulation of tourism at the regional level]. Dissertation of the Candidate of State Administration. Donetsk, Ukraine

Delgado, M., Porter, M.E., \& Stern, S. (2015). Defining clusters of related industries. Journal of Economic Geography, 16(1), 1-38.

Dmytrenko, V. (2008). Derzhavne rehuliuvannia rehionalnoho rekreatsiino-turystychnoho kompleksu [State regulation of the regional recreational and tourist complex].: Dissertation of the Candidate of Public administration. Zaporozhye, Ukraine

Dzhadzhuhazova, E. (2005). Formirovanie strategii razvitiya regional'nogo turistsko-rekreacionnogo kompleksa [Formation of a strategy for the development of a regional tourist and recreational complex]. Dis. Doctor of Economic Sciences. Moscow, Russia.

Enright, M. (2000). Survey on the Characterization of Regional Clusters: Initial Results. Working Paper, Institute of Economic Policy and Business Strategy: Competitiveness Program, University of Hong Kong, Sun Hung Kai. Available at: http://www.pacaonline.org/cop/docs/Michael_Enright_Survey_on_the_characterization_of_regional_clusters.pdf

Enright, M. (1996). Regional Clusters. Economic Development: A Research Agenda. Business Network: Prospects for Regional Development. Berlin: Walter de Gruyter. pp. 190-213. 
Enright, M.J. (2001). Regional clusters. What we know and what we should know, Kiel Institute International Workshop on Innovation Clusters and International Competition, 12-13 November 2001, Kiel, Germany.

European Commission (2002). Regional clusters in Europe. Observatory of European SMEs 2002, 3, Enterprise publications.

Fedorets, L. (2011). Ocenka effektivnosti deyatel'nosti turisticheskogo klastera [Evaluation of the effectiveness of the tourism cluster]. Vector of science of Togliatti State University. Seria Economics and Management, 1 (4), 42-45, (in Russian).

Feser, E., Renski, H., \& Goldstein, H. (2008). Clusters and Economic Development Outcomes. An Analysis of the Link Between Clustering and Industry Growth. 22(4), 324-344. https://doi.org/10.1177/0891242408325419

Fomenko, N. (2007). Rekreatsiini resursy ta kurortolohiia [Recreational resources and balneology]. Center for Educational Literature, Ukraine.

Golik, Yu., \& Maksimova, I. (2013). Formirovanie otraslevogo nabora pokazatelej avtomobil'nogo klastera [Formation of a sectoral set of indicators for the automotive cluster]. Microeconomics, 4, 28-32, (in Russian).

Halachieva, L. (2006). Formirovanie i razvitie territorial'no-rekreacionnogo kompleksa Kabardino-Balkarii [Formation and development of the territorial and recreational complex of Kabardino-Balkaria]. Dissertation of the Candidate of Geographical Sciences. Stavropol, Russia.

Hanushchak Efimenko, L. (2010). Konkurentnye preimushchestva klasteroob"edinennyh predpriyatij na rynke [Competitive advantages of cluster-united enterprises in the market]. Actual problems of the economy, 3 (105), 143-147, (in Ukrainian).

Iordache, C., Ciochină, I., \& Asandei, M. (2010). Clusters tourism activity increase competitiveness support. Theoretical \& Applied Economics, 17(5), 99-112.

Kachniewska, M. (2006). Tourism Quality Management. WSHiFM, Warsaw, Poland.

Kalashova, M. (2009). Aktivizaciya razvitiya turistsko-rekreacionnogo kompleksa: faktory i regulyatory (na materialah Respubliki Adygeya) [Enhancing the development of the tourist and recreational complex: factors and regulators (based on the materials of the Republic of Adygea)]. Dis. Cand. econom. sciences. Maykop, Russia.

Koblova, A. (2005). Rekreacionno-turistskij kompleks kak ob"ekt regional'nogo upravleniya [Recreational and tourist complex as an object of regional management]. Collection of scientific works of SevKavGTU. Seria Economy, 2, 110-121, (in Russian).

Kotlyarov, E. (1978). Geografiya otdyha i turizma. Formirovanie i razvitie territorial'nyh rekreacionnyh kompleksov [Recreation and tourism geography. Formation and development of territorial recreational complexes]. Mysl, Russia.

Kraynyk, A., \& Biel, M. (2009). Turisticheskij klaster regiona kak forma social'nogo dialoga: upravlencheskij aspect [Tourist cluster of the region as a form of social dialogue: management aspect]. Scientific bulletin «Democratic management», 4.

Makekadyrova, A. (2008). Razvitie sistemy upravleniya formirovaniem i funkcionirovaniem turistsko-rekreacionnogo kompleksa Rossii [Development of a management system for the formation and functioning of the tourist and recreational complex of Russia]. Doctoral Dissertation of Economics sciences. Moscow, Russia.

Marshall, A. (1920). Principals of Economics. Macmillan, London, United Kingdom.

Musienko, M., Serebriakov, V., \& Braion O. (2004). Ekolohiia: tlumachnyi slovnyk [Ecology: an explanatory dictionary]. Lybid, Ukraine.

Myhaylichenko, G. (2012). Formation of innovative tourism clusters as a competitive advantage of the region's development. Management and Entrepreneurship in Ukraine: Stages of Formation and Problems of Development, 4(38), 341-349.

Nesterchuk, I., Osipchuk, A., Bondarenko, E., Trusij, O., Ivanenko, V., \& Chyzhevska, L. (2021). Reloading of gastronomy tours in the conditions of using the Right-Bank Polissia gastronomy potential. GeoJournal of Tourism and Geosites, 34(1), 170-176. https://doi.org/10.30892/gtg.34122-633

Pashentseva, G. (2011). Teoretychni pidkhody vyznachennia sutnosti definitsii rekreatsiina terytoriia [Theoretical approaches to determining the essence of the definition of recreational area]. Culture of the peoples of the Black Sea region, 212, 195-196, (in Ukrainian).

Porter, M. (2011). Konkurentnaya strategiya: Metodika analiza otraslej i konkurentov [Competitive strategy: Methods for analyzing industries and competitors]. Alpina Publisher, Russia.

Preobrazhensky, V., \& Vedenin, Yu. (1971). Geografiya i otdyh [Geography and rest]. Knowledge, Russia.

Rosenthal, S.S., \& Strange, W.C. (2004). Evidence on the Nature and Sources of Agglomeration Economies. Handbook of Regional and Urban Economics, 4, Elsevier Publishers.

Senova, A. (2011). Regional'nye osobennosti razvitiya turistsko-rekreacionnogo kompleksa Kabardino-Balkarskoj respubliki [Regional features of the development of the tourist and recreational complex of the Kabardino-Balkarian Republic]. Dissertation of the Candidat of Economical Sciences. Moscow, Russia.

Shapovalova, N. (2006). Sovershenstvovanie upravleniya resursnym obespecheniem turistsko-rekreacionnogo kompleksa (na materialah Respubliki Adygeya) [Improving the resource management of the tourist and recreational complex (based on the materials of the Republic of Adygea)] . Dissertation of the Candidat of Economical Sciences, Maikop, Russia.

Sharafutdinov, V. (2000). Kurortno-turystychnyi kompleks Sochi: rozvytok v umovakh rynku [Sochi resort and tourist complex: development in market conditions]. Institute of Economics, Russian Academy of Sciences, Russia.

Trusova, N., Cherniavska, T., Pasieka S., Hranovska, V., Prystemskyi, O., \& Demko, V. (2020). Innovative clustering of the region in the context of increasing competitive positions of the enterprises of the tourist-recreational destination. GeoJournal of Tourism and Geosites, 31(3), 1126-1134. https://doi.org/10.30892/gtg.31326-549

Tyshchenko, S. (2019). Derzhavno-pryvatne partnerstva v konteksti systemnoho rozvytku [Sovereign-private partnership in the context of systemic development]. Geography and tourism. 49. 24-37, (in Ukrainian).

Vasylykha, N., Indus, K., \& Gotko, N. (2017). Kontseptualni zasady efektyvnosti funktsionuvannia rynku turystychnykh posluh [Conceptual principles of efficiency of functioning of the market of tourist services]. Scientific herald of Uzhhorod university, Economics series, 1 (49), 177-181, (in Ukrainian).

Weber, A. (1929). Theory of the Location of Industries. University of Chicago Press. Chicago, USA

Zorin, I., \& Kvartalnov, V. (2003). Enciklopediya turizma [Encyclopedia of Tourism]. Finance and Statistics, Russia.

*** Competitive Regional Clusters: National Policy Approaches (2007). Paris: OECD Publishing, 354. https://doi.org/10.1787/9789264031838-en

Article history: $\quad$ Received: 19.05.2021 Revised: 04.09.2021 Accepted: 05.10.2021 Available online: 28.10.2021 